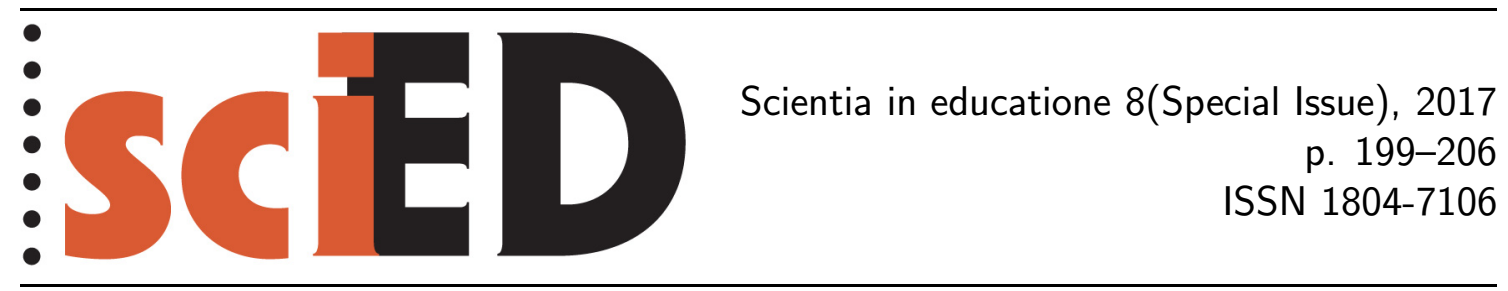

\title{
Increasing Physics Teacher Production by Replicating the UTeach Preparation Model and Awarding Noyce Scholarships
}

\author{
Gregory R. Hale, Ramon E. Lopez, \\ Ann M. L. Cavallo, Erin E. Gonzales
}

\begin{abstract}
In order to improve the production of physics teachers, and high school science teachers in general, at The University of Texas at Arlington, the authors obtained grant funding to offer National Science Foundation Robert Noyce Teacher Scholarships and to support a replication of the successful UTeach science and mathematics teacher preparation program. The Noyce grant was obtained first, and a modest increase in science teacher production was seen. The UTeach replication has been implemented on a four-year schedule, culminating in the establishment of a new student teaching program in January 2014. The combination of a UTeach replication and availability of Noyce Scholarships has UT Arlington poised to improve its science teacher production by an order of magnitude.
\end{abstract}

Key words: teacher training, teacher preparation, university education, secondary education: upper. 


\section{INTRODUCTION}

The preparation of an adequate number of very well qualified secondary science and mathematics teachers is a well-publicized problem in the United States. In particular, the preparation of physics teachers has greatly lagged the need for highly qualified classroom instructors. The state of Texas, home to the authors, is not immune from this issue. In fact, physics teacher production in Texas (Table 1) is far from in line with what should be expected from a state with a population of over 26000000 .

Table 1: Physics and other physical science teacher production in Texas, 2006 to 2012

\begin{tabular}{c|c|c|c|c}
\hline $\begin{array}{c}\text { Academic } \\
\text { Year }\end{array}$ & $\begin{array}{c}\text { 8-12 Physics-Math } \\
\text { Teacher } \\
\text { Production }\end{array}$ & $\begin{array}{c}\text { 8-12 Physical } \\
\text { Science } \\
\text { Teacher } \\
\text { Production }\end{array}$ & $\begin{array}{c}\text { 8-12 Physical } \\
\text { Science-Math- } \\
\text { Engineering } \\
\text { Teacher } \\
\text { Production }\end{array}$ & $\begin{array}{c}\text { 8-12 Chemistry } \\
\text { Teacher } \\
\text { Production }\end{array}$ \\
\hline $2006-2007$ & 20 & 88 & NA & 49 \\
\hline $2007-2008$ & 27 & 74 & 3 & 68 \\
\hline $2008-2009$ & 17 & 56 & 5 & 72 \\
\hline $2009-2010$ & 31 & 55 & 9 & 60 \\
\hline $2010-2011$ & 37 & 34 & 8 & 36 \\
\hline $2011-2012$ & 27 & 24 & 7 & 36 \\
\hline
\end{tabular}

While it would be nice to say that our institution, The University of Texas at Arlington (UT Arlington), had been a shining example during this period, we cannot. Our production of teachers in the physical sciences was similarly lacklustre (Table 2).

Table 2: Physics and other physical science teacher production at The University of Texas at Arlington, 2006 to 2013

\begin{tabular}{l|c|c|c|c}
\hline $\begin{array}{c}\text { Academic } \\
\text { Year }\end{array}$ & $\begin{array}{c}8-12 \text { Science } \\
\text { Teacher } \\
\text { Production }\end{array}$ & $\begin{array}{c}8-12 \text { Physics } \\
\text { Teacher } \\
\text { Production }\end{array}$ & $\begin{array}{c}\text { 8-12 Physical } \\
\text { Science } \\
\text { Teacher } \\
\text { Production }\end{array}$ & $\begin{array}{c}8-12 \text { Chemistry } \\
\text { Teacher } \\
\text { Production }\end{array}$ \\
\hline $2006-2007$ & 1 & 0 & 0 & 0 \\
\hline $2007-2008$ & 2 & 0 & 0 & 0 \\
\hline $2008-2009$ & 1 & 0 & 0 & 0 \\
\hline $2009-2010^{*}$ & 1 & 0 & 0 & 0 \\
\hline $2010-2011$ & 6 & 0 & 1 & 0 \\
\hline $2011-2012$ & 5 & 1 & 0 & 0 \\
\hline $2012-2013$ & 3 & 0 & 0 & 0 \\
(partial) & 3 & 0 & & 0 \\
\hline
\end{tabular}

*first year Noyce Scholarships awarded at UT Arlington

Author Hale began to explore options for improving secondary math and science teacher production at UT Arlington in late 2006. Soon thereafter, the UT Arlington Provost, Dean of Science and author Hale met with the Dean of Natural Sciences from The University of Texas at Austin (UT Austin) to learn about the UTeach program. Author Hale then visited UT Austin and spoke with UTeach Co-Directors and 
Master Teachers about the program. (Coincidentally, author Lopez, then with the Florida Institute of Technology, was visiting UTeach Austin as a seminar speaker at the same time.) Upon learning that a competition would be announced in the coming months for UTeach replication grants, authors Hale and Cavallo began preparing a submission. Author Lopez was hired by UT Arlington in the midst of this process, and he contributed to the preparation prior to his arrival on campus for the 2007-2008 academic year.

To help illustrate why the UTeach teacher preparation approach was attractive to the authors, provided below is a description of the origin of UTeach from the UTeach Austin web site (The University of Texas at Austin, n.d.a).

Beginning in 1997, The University of Texas at Austin set out to effect long-term, systematic change in the way science and mathematics majors were being prepared for careers in secondary math or science education. The Dean of the College of Natural Sciences, Mary Ann Rankin, brought together a group of experienced secondary teachers and administrators and charged them to design an innovative teacher preparation program based on national standards, educational research, and their years of experience in the K-12 setting. As part of a substantially revised approach to teacher education called UTeach, the College of Natural Sciences employs several of the best high school science and math teachers in the state to lead the introductory UTeach courses and coordinate a range of on-going field-based experiences. To reinforce the value of such a career choice for students, the College of Natural Sciences offers a rebate for these introductory courses.

At the same time, the Dean of the College of Education, Manuel Justiz, undertook a major commitment to rebuild and strengthen the College's program in mathematics and science education. Under the leadership of Dr. Jere Confrey, mathematics and science education faculty made the decision to completely revise the professional development courses. They developed a three-course sequence that builds on research on student learning, the examination of standards-based curricula, the study of effective classroom interactions, and the development of models of teaching. Issues of technology use and effective approaches to equitable participation are embedded in all aspects of the program, culminating in students' teaching an entire unit in Project Based Instruction. In addition, the mathematics and science education faculty place students in high-need schools, where they learn firsthand of the needs, challenges and opportunities involved in these settings.

The UTeach program at UT Austin was successfully producing dozens of secondary math and science teachers instead of the low single digits that UT Austin had been producing before 1997. Even more impressive to the authors was the improved longevity that UTeach-prepared math and science teachers were exhibiting. Back in 2006, the data showed that more than $80 \%$ of UTeach Austin prepared teachers were still in the teaching profession after four years (Rankin, 2006). Compared to Ingersoll's data published in 2003 which showed that the four-year retention rate for all teachers was $60 \%$, it seemed that the UTeach approach was not only preparing more teachers, it was producing better prepared teachers (Ingersoll, 2003).

At the same time that the authors were preparing the UTeach replication proposal, funding was also sought from the National Science Foundation's (NSF) Robert Noyce Teacher Scholarship program (National Science Foundation web site, n.d.). From 2008 to 2010, the authors had two Noyce proposals funded. The first was for candidates seeking certification as physics, chemistry or math secondary teachers, and the second covered candidates seeking secondary life science or middle level math and science teacher certification. 


\section{Methods}

The NSF Noyce Scholarship grants allowed UT Arlington to offer full tuition scholarships to junior and senior science and math majors preparing for teacher certification, renewable for up to two years of support. In addition, post-baccalaureate candidates could also be supported for one year as they worked towards teacher certification. Scholarships were awarded to math, chemistry and physics teacher certification candidates beginning in 2009. Scholarships were awarded to life science and middle level teacher certification candidates beginning in 2011.

These scholarships were marketed with flyers on our campus, classroom visits by grant personnel in classes where sophomore and junior science and math majors were in high proportion, and flyers at the nearest community college to reach transfer students. Once our UTeach replication was running sophomore level courses (20112012 academic year), marketing efforts were also made to particularly target these students.

Authors Hale, Lopez and Cavallo as Co-Directors received a UTeach Replication Grant from the National Math and Science Initiative in September 2009, and the program recruited its first 89 students in the fall of 2010. Between September 2009 and August 2010, the Co-Directors hired the initial UTeach Arlington staff and began revising degree plans and creating new coursework. That is to say, the CoDirectors started to put in place the Elements of Success (The University of Texas at Austin, n.d.b) of a UTeach replication.

- Distinctive Program Identity.

- Cross-College and School District Collaboration.

- Long-Term Institutional and Community Support.

- Compact and Flexible Degree Plans.

- Active Student Recruitment and Support.

- Dedicated Master Teachers.

- Rigorous, Research-Based Instruction.

- Early and Intensive Field Experiences.

- Continuous Program Improvement.

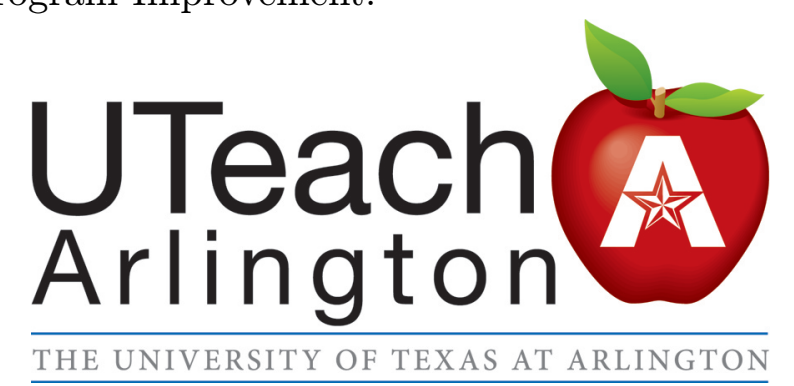

Figure 1: Distinctive program identity: UTeach Arlington logo

Special emphasis was placed on certain elements of success at UT Arlington. For example, the Co-Directors immediately created a UTeach Arlington identity by designing a logo and launching a program web site (http://www.uta.edu/uteach). In addition, contiguous space in the university's oldest science building was allocated to UTeach Arlington. Once renovations were complete, the UTeach Arlington logo (Figure 1) was installed by the entrance to each office, conference room, classroom, and even storage rooms to give UTeach Arlington students the feeling of being 
at their academic home when they were going to their UTeach classes. To reinforce this sense of identity, UTeach Arlington students are provided with a student lounge, equipped with computers, a scanner, a printer, education journals, and other resources. The lounge is well attended by students looking to get some work done and students that simply want to relax and socialize until their next class starts.

The Co-Directors extended the Dedicated Master Teachers element of success to all UTeach Arlington hires. The first four hires were for a business manager, academic advisor, science master teacher and math master teacher. All four hires proved to be extremely dedicated personnel. All have contributed mightily to the sense of community that UTeach Arlington students experience. The master teachers were veteran classroom teachers who each also had administrative experience. Their expertise and network of colleagues in area school districts proved to be invaluable in continuing to fulfil another UTeach Element of Success - School District Collaboration. Subsequent hires of two master teachers and an accountant proved to be equally strong. All of the UTeach Arlington master teachers and staff are solutions-focused and student-centered.

The Active Student Recruitment and Support Element of Success is anchored at UTeach Arlington by the dedicated academic advisor (author Gonzales). The UTeach Arlington academic advisor is dedicated in two senses of the word. Firstly, she only advises UTeach Arlington students. Secondly, she works exceptionally hard to keep UTeach Arlington students on the path to success. To date, author Gonzales has also been responsible for the most effective recruiting strategy. She visits each College of Science freshman and transfer student orientation (mandatory for UT Arlington students) and makes a three-minute pitch to the students and their parents. The presence of the parents during this recruiting pitch appears to be important. When the recruiting pitch mentions a strong job market for math and science teachers and the availability of substantial financial aid, the parents are observed to be paying close attention. The typical result of this recruiting strategy is full sections of the first course in the UTeach sequence. The original master teacher hires, subsequent master teacher hires (also very experienced in the classroom and administration), and subsequent office staff hire have formed a very dedicated and enthusiastic team. Wherever a potential UTeach Arlington student turns for help, he or she will find someone more than willing to resolve his or her questions.

The UTeach Arlington team has also worked hard to ensure that we offer Compact and Flexible Degree Plans. Whether a UTeach Arlington student joins us as a first-time freshman or a transfer student, they will find a pathway through our program already mapped out for them (Figure 2). Our academic advisors also prepare a customized plan for each student, outlining the courses he/she should take each semester until graduation.

As far as Rigorous, Research-Based Instruction is concerned, our pedagogical methods are centered on the learning cycle and its $5 \mathrm{E}$ lesson plan implementation. The Master Teachers provide a basic introduction to the Learning Cycle in the STEP 1 and STEP 2 recruitment courses. UTeach Arlington students put this knowledge into field practice in these first two UTeach courses, delivering $5 \mathrm{E}$ lessons in the classroom of a mentor elementary or middle school teacher. Subsequent UTeach coursework provides the learning research and educational psychology foundation of the learning cycle, further training in learning cycle teaching methods, and classroom management skills. In all, there are four courses in the UTeach program prior to student teaching that have field experience components. All courses in the UTeach Arlington program are described in Table 3. 
Table 3: UTeach Arlington course descriptions

\begin{tabular}{|c|c|}
\hline Course Name & Course Description \\
\hline$\overline{\text { STEP } 1}$ & $\begin{array}{l}\text { Introduction to mathematics and science teaching as a career. } \\
\text { Discussions include standards-based lesson design and various teaching } \\
\text { and behavior management strategies. Fieldwork consists of planning and } \\
\text { teaching three inquiry-based lessons to students in grades three to six in } \\
\text { local elementary schools. One and one-half class hours a week for one } \\
\text { semester; at least ten hours of fieldwork a semester are also required. }\end{array}$ \\
\hline$\overline{\text { STEP } 2}$ & $\begin{array}{l}\text { Topics may include routes to teacher certification in mathematics, } \\
\text { computer sciences, and science teaching; various teaching methods that } \\
\text { are designed to meet instructional goals; and learner outcomes. Students } \\
\text { develop and teach three inquiry-based lessons in their field in a middle } \\
\text { school, and participate in peer coaching. One and one-half class hours a } \\
\text { week for one semester; at least twenty hours of fieldwork a semester are } \\
\text { also required. }\end{array}$ \\
\hline $\begin{array}{l}\text { Knowing } \\
\text { \& Learning }\end{array}$ & $\begin{array}{l}\text { Restricted to students in the UTeach Arlington program. Psychological } \\
\text { foundations of learning; problem solving in mathematics and science } \\
\text { education utilizing technology; principles of expertise and novice } \\
\text { understanding of subject matter; implications of high-stakes testing; and } \\
\text { foundations of formative and summative assessment. Three lecture hours } \\
\text { a week for one semester; additional hours may be required. }\end{array}$ \\
\hline $\begin{array}{l}\text { Classroom } \\
\text { Interactions }\end{array}$ & $\begin{array}{l}\text { Restricted to students in the UTeach Arlington program. Principles of } \\
\text { delivering effective instruction in various formats (lecture, lab activity, } \\
\text { collaborative settings); examination of gender, class, race, and culture in } \\
\text { mathematics and science education; overview of policy related to } \\
\text { mathematics and science education. Three lecture hours a week for one } \\
\text { semester; additional hours may be required. }\end{array}$ \\
\hline $\begin{array}{l}\text { Perspectives } \\
\text { on Science } \\
\text { And } \\
\text { Mathematics }\end{array}$ & $\begin{array}{l}\text { An examination of five notable episodes in the history of science: } \\
\text { Galileo's conflict with the Catholic Church, Isaac Newton's formulation } \\
\text { of the laws of motion, Charles Darwin's proposal of the theory of } \\
\text { evolution by natural selection, the development of the atomic bomb, and } \\
\text { the discovery of the double helix structure of DNA. Three lecture hours } \\
\text { and one discussion hour a week for one semester. }\end{array}$ \\
\hline $\begin{array}{l}\text { Research } \\
\text { Methods }\end{array}$ & $\begin{array}{l}\text { Primarily a laboratory course where students develop and practice skills } \\
\text { fundamental to the scientific enterprise. Research Methods is organized } \\
\text { around four independent inquiries that students design and carry out. } \\
\text { The course emphasizes the use of mathematics to model and explain both } \\
\text { the natural and man-made worlds, and requires a substantial amount of } \\
\text { writing. Research Methods emphasizes the development of skills that are } \\
\text { directly applicable in teaching secondary science and mathematics (e.g. } \\
\text { use of equipment, preparation of lab materials, safety issues, use of } \\
\text { technology). }\end{array}$ \\
\hline $\begin{array}{l}\text { Multiple } \\
\text { Teaching } \\
\text { Practices }\end{array}$ & $\begin{array}{l}\text { Foundations of project-based, case-based, and problem-based learning } \\
\text { environments; principles of project-based curriculum development in } \\
\text { mathematics and science education; classroom management and } \\
\text { organization of project-based learning classrooms. Three lecture hours a } \\
\text { week for one semester with additional fieldwork hours to be arranged. }\end{array}$ \\
\hline $\begin{array}{l}\text { Student } \\
\text { Teaching }\end{array}$ & $\begin{array}{l}\text { Supervised and directed practice in an approved field setting. The } \\
\text { student will be assigned based on the cooperating school district } \\
\text { calendar. Required seminars will provide students with theory to } \\
\text { integrate and apply during residency. }\end{array}$ \\
\hline
\end{tabular}




\section{UTeach Arlington Entry Points}

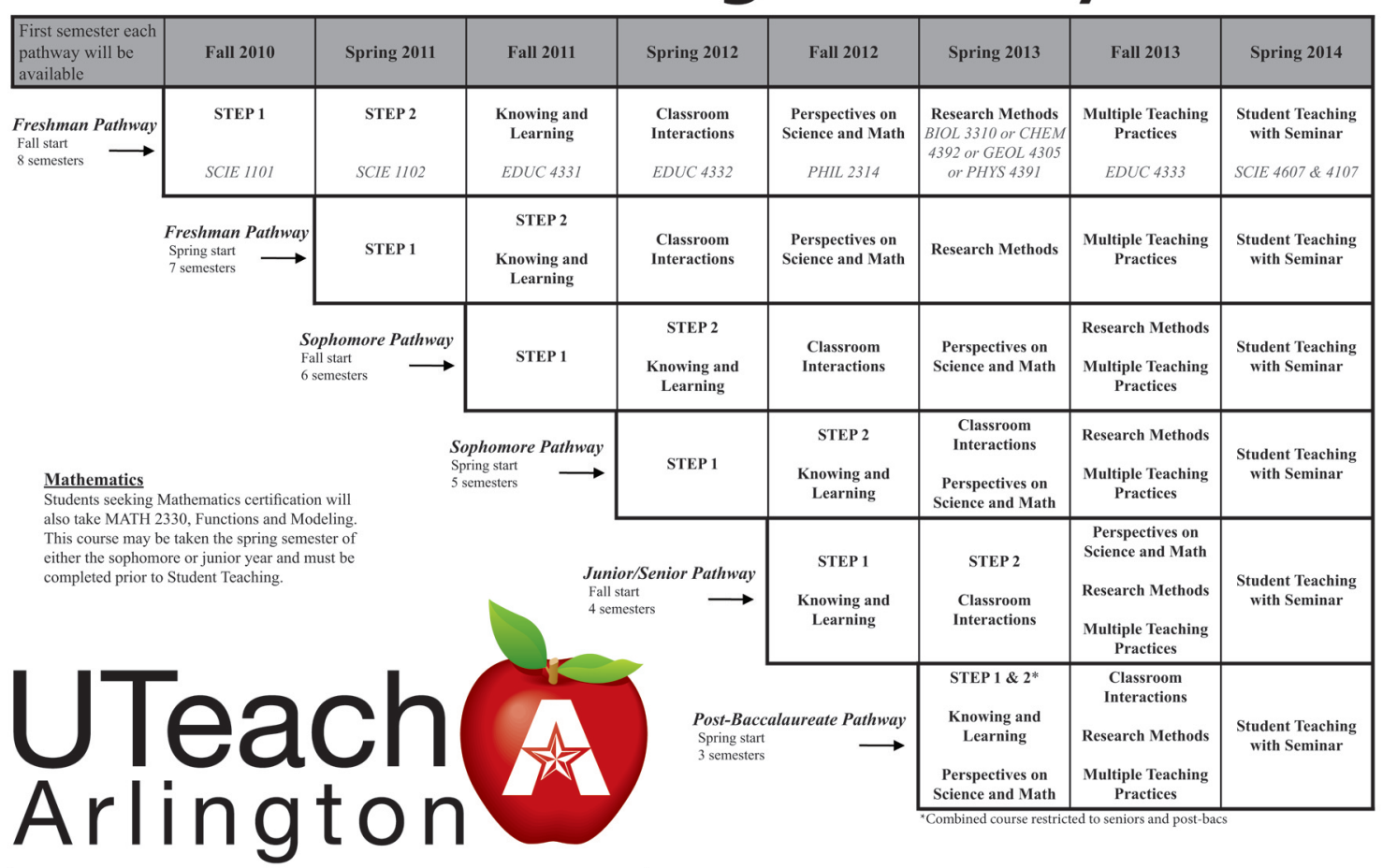

THE UNIVERSITY OF TEXAS AT ARLINGTON

Figure 2: UTeach Arlington entry points

\section{RESULTS}

While students supported by Noyce Scholarships have finished their preparation programs, no UTeach Arlington student has graduated yet. The 2013-2014 academic year is the last year of our new course rollout. UTeach Arlington students will have their first opportunities to enter into Student Teaching in January and August of 2014. The first impacts of the Noyce Scholarships are evident in Table 2. Whereas typically one high school science teacher was prepared per year at UT Arlington, and zero physics teachers, awarding Noyce Scholarships moved the total up to five or six science teachers per year, including the first physics teacher produced in a number of years. The effectiveness of our UTeach replication can be seen in our secondary science and math teacher pipeline data (Table 4). There are approximately $60 \mathrm{stu}-$ dents on track to enter into secondary science and mathematics student teaching in 2014.

Table 4: Secondary science and math teacher pipeline at UT Arlington

\begin{tabular}{l|c|c|r|r|r|r}
\hline Major & Fall 2010 & Spring 2011 & Fall 2011 & Spring 2012 & Fall 2012 & Spring 2013 \\
\hline Physics & 2 & 3 & 4 & 12 & 12 & 11 \\
\hline Biology & 48 & 36 & 71 & 59 & 79 & 54 \\
\hline Chemistry & 7 & 5 & 15 & 10 & 12 & 5 \\
\hline Geology & 2 & 1 & 1 & 3 & 9 & 8 \\
\hline Math & 12 & 15 & 33 & 33 & 69 & 59 \\
\hline Other & 18 & 34 & 30 & 30 & 26 & 25 \\
\hline Total & 71 & 60 & 124 & 117 & 182 & 137 \\
\hline
\end{tabular}




\section{Conclusions}

The introduction of NSF Robert Noyce Teacher Scholarships on the UT Arlington campus did drive an increase in the production of science teachers. While that increase looks impressive on a percentage basis, it moved UT Arlington only into the mid-single digits of science teacher production, and physics teacher production was still rare. While this improvement was welcome, it was much more modest than our goals. Our Noyce Scholarship intervention would have likely produced a larger increase if the authors were not also actively working on the UTeach replication project. Once the UTeach replication was begun, the Noyce Scholarship program became a more complementary project than a stand-alone effort.

The combined approach of a UTeach replication supplemented with a Noyce Scholarship program is poised to produce dramatic results at UT Arlington. Our first class of UTeach Arlington trained secondary math and science teachers will enter student teaching the spring and fall of 2014. It is anticipated that there will be more than 50 student teachers. Approximately half will be science teachers and half math teachers, and there will be multiple physics majors in the group. While the authors do not feel that we will be producing enough physics (or chemistry) teachers yet, this is a very promising start.

\section{ACKNOWLEDGEMENT}

This work was supported by Texas Instruments, AT\&T, the Michael and Susan Dell Foundation, the Texas Education Agency, the Sid Richardson Foundation, the George and Fay Young Foundation, and the U.S. National Science Foundation grant \#0833343 under the Robert Noyce Scholarship Program for Teachers of Science and Mathematics.

\section{REFERENCES}

Ingersoll, R. (2003). Is there really a teacher shortage? A research report co-sponsored by The Consortium for Policy Research in Education and The Center for the Study of Teaching and Policy.

National Science Foundation web site. (n.d.). Available at http://www.nsf.gov/funding/pgm_summ.jsp?pims_id=5733

Rankin, M. A. (2006). UTeach Natural Sciences overview presentation. 29 November 2006, Fort Worth, TX.

The University of Texas at Austin. (n.d.). UTeach Natural Sciences web site. Available at https://uteach.utexas.edu/About/Program\%20History

The University of Texas at Austin. (n.d.). UTeach Natural Sciences web site. Available at http://uteach-institute.org/publications

Gregory R. HALE

RAMON E. LOPEZ

Ann M.L. Cavallo

ERIN E. Gonzales

UTeach Arlington, The University of Texas at Arlington, Arlington, TX, USA 